\title{
Z DZIAEALNOSCI POLSKIEgo TOWARZYSTWA TEOLOGICZNEGO W KRAKOWIE W R. 1971
}

Polskie Towarzystwo Teologiczne w Krakowie zgodnie ze swoim statutem prowadziło w r. 1971 działalność odczytową, która była realizowana na zebraniach zwyczajnych oraz w pracach poszczególnych sekcji. Zebrania zwyczajne odbywaly się $w$ rezydencji metropolity krakowskiego.

W okresie sprawozdawczym odbyło się 9 ogólnych zebrań zwyczajnych z następującymi referatami:

1) Ks. dr D. Nowicki: Trudność $w$ realizowaniu ruchu ekumenicznego (18. 2. 1971).

2) Ks. dr J. Sieg SJ: W poszukiwaniu nowych form szkolnictwa $w$ krajach trzeciego świata (18. 3. 1971).

3) O. dr A. Szymański OFM: Antoni Wegrzynowicz, wielki Polak, kaznodzieja Krakowa, rzecznik idei sprawiedliwości społecznej, jako nauczyciel $i$ wychowawca narodu (15. 4. 1971).

4) Doc. dr J. Mitkowski: Sw Stanisław Biskup Szczepanowski a Bolesław Smiaty (13. 5. 1971).

5) O. Dr Lisowski OFM Conv: Wkład O. Maksymiliana Kolbego $w$ odrodzenie religijno-moralne polskiego społeczeństwa katolickiego okresu dwudziestolecia (13. 9. 1971).

6) Ks. prof. dr W. Gnutek: Objaśnienia niektórych trudniejszych tekstów Nowego Testamentu (14. 10. 1971).

7) Ks. dr W. Swie rzawski: Chrześcijańskie misterium śmierci (18. 11. 1971).

8) Ks. Rektor dr J. M a j k a : Obraz krzywd społecznych $w$ świetle obrad Synodu Biskupów (16. 12. 1971).

9) Ks. dr J. Sieg SJ: O liście apostolskim Pawła VI ,Octogesima adveniens" (21. 1. 1972).

Sekcja biblijno-liturgiczna odbyła 5 zebrań, na których wygłoszono następujące referaty:

1) Ks. prof. dr Władysław Smereka: Szkoły biblijne $w$ Jerozolimie (24. 2. 1971).

2) Ks. dr Władysław B o r ow s k i CRL: Psalm 131 i jego nauka (17.3.1971).

3) O. prof. dr Augustyn Jankowski OSB: Sens trzech przenośni Pawłowych: ,pierwsze dary” — ,zadatek” — ,opieczętowanie” (Rz 8, 23; 2 Kor 1, 22; 5, 5; Ef 1, 13n; 4, 30). Przyczynek do nowotestamentalnej teologii Ducha Swiętego (28. 4. 1971).

4) Ks. dr Jerzy Chmie 1: Perspektywy apostolatu biblijnego. Sprawozdanie z Kongresu Apostolatu Biblijnego $w$ Rocca di Papa - lipiec 1971 (10. 11. 1971).

5) O. dr Ludwik M y cielski OSB: Brewiarz $w$ języku polskim. $Z$ doświadczeń w Opactwie Tynieckim (15. 12. 1971).

Posiedzenia naukowe odbywały również sekcje: filozoficzna, dogmatyczno-moralna, historyczno-prawna i pastoralna.

J. Ch. 